\author{
Wojciech Sadkowski \\ Uniwersytet Jagielloński, Kraków, Polska \\ Jagiellonian University, Cracow, Poland
}

\title{
Przegląd wybranej problematyki działalności usługowej
}

\section{Service Industries: an Overview of Selected Issues}

Streszczenie: Głównym celem artykułu jest przedstawienie najważniejszych funkcji usług oraz istoty działalności usługowej. Cel prowadzonych rozważań to również identyfikacja obszarów problemowych w zarządzaniu organizacjami usługowymi. W pierwszej części autor prezentuje definicje usługi oraz przedsiębiorstwa usługowego. W drugiej - przedstawia zestawienie najważniejszych cech usług odróżniających je od innych działalności. W trzeciej i czwartej części autor koncentruje się na funkcjach sektora usługowego oraz problemach w zarządzaniu przedsiębiorstwem usługowym. Obiektem badań jest usługa i związana z nią działalność usługowa, która odgrywa coraz istotniejszą rolę w polskiej gospodarce. W pracy przeprowadzono analizę piśmiennictwa naukowego z zakresu zarządzania jakością, ekonomiki usług, marketingu oraz zastosowano metody indukcji i dedukcji. Wg danych Ministerstwa Gospodarki z 2015 roku co drugi pracujący Polak znajduje zatrudnienie w usługach. W gospodarkach wysoko rozwiniętych aż $80 \%$ dochodu narodowego jest wytwarzane przez przedsiębiorstwa usługowe. Natomiast wkład sektora usługowego w tworzenie PKB Polski wzrósł z poziomu ok. $50 \%$ w latach dziewięćdziesiątych XX wieku do ok. $65 \%$ obecnie. Jakość realizowanych usług ma istotny wpływ na wyniki finansowe podmiotów tego sektora. Sukces na bardzo konkurencyjnym rynku usług może zapewnić tylko świadczenie usług najwyższej jakości.

Abstract: The main purpose of the article is to present the most important functions of services and the essence of service activity. Considerations lead to the identification of problematic areas in management of service organizations. In the first part, the author presents the definitions of services and service enterprise. The second item contains a summary of the most important features of services that distinguish them from other activities. In the third and fourth part, the author focuses on the functions of services sector, components of a service enterprise and problems in managing them. The research object is the service itself and associated service activity that plays an increasingly important role in Polish economy. The article contains an analysis of literature in the field of quality management, service economics, marketing and the methods of induction and deduction. According to the data of the Ministry of Economy from 2015, every second working Pole finds employment in services. In highly-developed economies, as much as $80 \%$ of the national income is generated by service companies. On the other hand, the contribution of the service sector to the creation of Polish GDP increased from around 50\% in the 1990s to around 65\% today. The quality of services provided has a significant impact on the financial results of entities in this sector. Success in a very competitive services market can be ensure only by the provision of top quality services.

Słowa kluczowe: cechy usług; funkcje usług; przedsiębiorstwo usługowe; usługa Keywords: service; service enterprise; service features; service functions 
Otrzymano: 13 grudnia 2017

Received: 13 December 2017

Zaakceptowano: 9 lutego 2018

Accepted: 9 February 2018

Sugerowana cytacja / Suggested citation:

Sadkowski, W. (2018). Przegląd wybranej problematyki działalności usługowej. Prace Komisji Geografii Przemysłu Polskiego Towarzystwa Geograficznego 32(1), 7-19. https://doi.org/10.24917/20801653.321.1

\section{WSTĘP}

Wysoko rozwinięte gospodarki są oparte na sektorze usługowym, który tworzy $80 \%$ ich dochodów narodowych. Natomiast wkład usług w tworzenie PKB Polski wzrósł z ok. 50\% w 1990 roku i kształtuje się obecnie na poziomie ok. 65\%. Zatrudnienie w usługach znajduje już co drugi pracujący (Polska 2015, 2015). Wysoka konkurencyjność sektora usług jest fundamentem gospodarek opartych na wiedzy, w których szczególną uwagę zwraca się na odpowiednią jakość świadczonych usług oraz produktów (Sadkowski, 2017).

Celem artykułu jest przedstawienie najważniejszych funkcji usług oraz istoty działalności przedsiębiorstw usługowych. Autor zwraca szczególną uwagę na jakość usług, która dla konsumenta jest niezmiernie ważnym elementem, wpływającym na jego satysfakcję.

W pierwszym podrozdziale zebrane zostały najważniejsze współczesne definicje usługi oraz przedsiębiorstwa usługowego. Kolejna część artykułu zawiera zestawienie najważniejszych cech różnicujących usługi od innych działalności. Następnie autor prezentuje funkcje sektora usługowego oraz podejmuje rozważania związane z problemami w zarządzaniu przedsiębiorstwami usługowymi.

\section{DEFINIOWANIE USŁUGI}

Usługa wg definicji „to każda czynność zawierająca w sobie element niematerialności, która polega na oddziaływaniu na klienta lub przedmioty bądź nieruchomości znajdujące się w jego posiadaniu, a która nie powoduje przeniesienia praw własności. Przeniesienie praw własności może jednak nastąpić, a świadczenie usługi może być lub też nie być ściśle związane z dobrem materialnym" (Bareja, Giedroyć, 2007: 36).

W ekonomii termin usługa jest definiowany jako „wszelkie czynności pożyteczne, związane z pracą nieprodukcyjną, w odróżnieniu od czynności prowadzących do produkcji dóbr materialnych" (Chrząścik, 2009: 174).

Współczesna literatura przedmiotu dostarcza bardzo różne definicje usług, które dzieli na negatywne, enumeratywne, konstruktywne i kompilacyjne (Panasiuk, 2005). Definicje negatywne zakładają, że działalnością usługową jest to, co nie jest wytwarzaniem dóbr materialnych (np. usługa fryzjerska, usługa telekomunikacyjna). Natomiast definicje enumeratywne wyliczają rodzaje działalności gospodarczej wchodzące w skład usług (np. Bank BGŻ BNP Paribas S.A., TLK MED Sp. z o.o.). W definicjach konstruktywnych określa się działalność usługową jako zdolność ludzi lub maszyn do wprowadzania zmian stanów u ludzi lub w obiektach (np. usługa masażu leczniczego, usługa dentystyczna). Definicje kompilacyjne odnoszą się zaś do usługi jako odrębnej działalności, która nie dostarcza materialnego charakteru i zapewnia nabywcy korzyści niezwiązane ze sprzedażą produktów (np. usługa kurierska, usługa hotelarska). 
W polskim ustawodawstwie usługa definiowana jest jako odpłatne świadczenie, wykonywane przez usługodawcę na własny rachunek (ustawa o świadczeniu usług). Prawo wspólnotowe Unii Europejskiej określa usługę jako świadczenie realizowane za wynagrodzenie i nie związane z przepływem towarów, kapitału i osób (traktat o funkcjonowaniu Unii Europejskiej).

Natomiast w definicji O. Langego usługi to czynności związane z zaspokojeniem potrzeb ludzkich, które nie służą bezpośrednio do produkcji dóbr materialnych (Lange, 1967).

R. Kolman charakteryzuje usługę jako użyteczne działanie człowieka, pracę lub proces, które zaspokaja określoną potrzebę (Kolman, 2013). Natomiast w ujęciu E. Michalskiego jest to produkt zawierający nieuchwytne komponenty, wymagający wysiłku ludzkiego i pracy sprzętu oraz urządzeń w celu jej wyświadczenia (Michalski, 2012). Autor definiuje usługę jako działanie niebędące produkcją i sprzedażą towarów, które zostało podjęte i jest realizowane przez usługodawcę na rzecz usługobiorcy (Sadkowski, 2017). Przegląd określeń tego pojęcia zawiera tab. 1.

Tab. 1. Przegląd definicji pojęcia usługi

\begin{tabular}{|l|l|}
\hline \multicolumn{1}{|c|}{ Autor } & \multicolumn{1}{|c|}{ Treść definicji } \\
\hline $\begin{array}{l}\text { Ustawa z dnia 4 marca 2010 roku } \\
\text { o świadczeniu usług na terytorium } \\
\text { Rzeczypospolitej Polskiej }\end{array}$ & $\begin{array}{l}\text { Świadczenie wykonywane przez usługodawcę na własny rachunek, } \\
\text { zwykle za wynagrodzenie, w szczególności usługi budowlane, } \\
\text { handlowe oraz usługi świadczone w ramach wykonywanego } \\
\text { zawodu }\end{array}$ \\
\hline $\begin{array}{l}\text { Traktat o funkcjonowaniu Unii } \\
\text { Europejskiej (art. 57) }\end{array}$ & $\begin{array}{l}\text { Jest to świadczenie, które nie jest sprzedażą towarów } \\
\text { i wykonywane jest zwykle za wynagrodzenie, w zakresie, jakim nie } \\
\text { jest objęte postanowieniami o swobodnym przepływie towarów, } \\
\text { kapitału i osób, w szczególności to działalność przemysłowa, } \\
\text { handlowa, rzemieślnicza oraz wykonywanie wolnych zawodów }\end{array}$ \\
\hline R. Kolman & $\begin{array}{l}\text { Użyteczne działanie człowieka, praca lub proces, który nie daje } \\
\text { nowego materialnego przedmiotu, ale zaspokaja określoną } \\
\text { potrzebę. Może ona uzdatniać lub usprawniać przedmiot działania, } \\
\text { bądź umożliwiać zmianę warunków postępowania osoby }\end{array}$ \\
\hline E. Michalski & $\begin{array}{l}\text { Produkt z dominującymi, nieuchwytnymi komponentami, które } \\
\text { wymagają wysiłku ludzkiego oraz często pracy sprzętu i urządzeń } \\
\text { w celu jej świadczenia }\end{array}$ \\
\hline O. Lange & $\begin{array}{l}\text { Czynność związana z zaspokojeniem potrzeb ludzkich, które nie } \\
\text { służą bezpośredniej produkcji dóbr materialnych }\end{array}$ \\
\hline W. Sadkowski & $\begin{array}{l}\text { Każde działanie, niebędące produkcją i sprzedażą towarów, } \\
\text { podjęte i zrealizowane przez usługodawcę na rzecz usługobiorcy }\end{array}$ \\
\hline
\end{tabular}

Źródło: opracowanie własne

Różnorodność definicji usług wynika z dużego zróżnicowania samych usług. Wspólnym elementem jest uwypuklenie przez autorów niematerialnego charakteru usługi oraz wskazanie, że działalność usługowa nie dotyczy produkcji. Każda z definicji porządkuje w sposób zrozumiały to określenie i pozwala na spojrzenie na usługę z różnych perspektyw.

Ponadto usługi są bardzo rozległym i zróżnicowanym sektorem gospodarki, który obejmuje działalność agend rządowych (policji, wojska, wymiaru sprawiedliwości), instytucji non profit oraz wszystkich prywatnych przedsiębiorstw, których głównym celem jest osiąganie zysku, takich jak banki, hotele, przedsiębiorstwa transportowe, instytucje finansowe itp. (Panasiuk, Tokarz, 2008). 
Sektor usług w rozumieniu S. Illerisa ma znaczący wpływ na rozwój społeczno-gospodarczy kraju i regionów - kreuje nowe miejsca pracy, przyczynia się do wzrostu dochodu i pozwala zaspokajać potrzeby mieszkańców (Illeris, 1996).

W świetle przedstawionych definicji pojęcia usługi przedsiębiorstwo usługowe określa się jako organizację, która swoje produkty dostarcza bezpośrednio do klienta, np. szpitale - usługi zdrowotne, szkoły - usługi edukacyjne, restauracje - usługi gastronomiczne, banki - usługi finansowe. Podmioty świadczące usługi od podmiotów produkcyjnych wyróżnia bezpośredni kontakt klienta i usługodawcy (Drummond, 1998).

W definicji A. Gilmore'a przedsiębiorstwo usługowe to jednostka prowadząca działalność w sektorze usług (np. restauracja) i niezorientowana na przynoszenie zysków (np. instytucja charytatywna) (Gilmore, 2006). Określenie to jest bardzo kontrowersyjne, ponieważ celem większości podmiotów usługowych jest generowanie zysków. Tylko organizacje typu non profit mają odmienne cele i skupiają się na wspieraniu prywatnego lub publicznego dobra.

\section{Cechy ustug}

Przedsiębiorstwa usługowe są specyficznymi podmiotami gospodarczymi. Wyróżniają się niematerialnością, równoczesnością procesów produkcji, dystrybucji i konsumpcji, heterogenicznością, niemożnością przechowania dla celów przyszłej konsumpcji oraz brakiem możliwości nabycia praw własności (Gustafsson, Johnson, 2003).

Wszystkie wymienione powyżej atrybuty są niezmiernie ważne w procesie zrozumienia istoty działalności usługowej. Niematerialność oznacza, że niemożliwa jest ocena danej usługi przez nabywcę przed jej zakupem, a za urealnienie tej usługi odpowiada świadczący podmiot. Jednoczesność świadczenia przez usługodawcę i konsumowania przez klienta wpływa na bezpośredni kontakt pomiędzy tymi dwoma zainteresowanymi stronami. Usługi nie są jednolite, standardowe, ich urozmaicenie zależy od wykonawcy, czasu i miejsca. Magazynowanie ich oraz dopuszczenie do wtórnego obrotu również nie jest możliwe.

Rozszerzoną charakterystykę usług prezentuje J.M. Rathmell. Wskazuje on 13 elementów, które determinują ich unikalność. Zalicza do nich:

- monetarną wartość usług wyrażaną w opłatach, prowizjach, potrąceniach, procentach, udziałach, dotacjach, która jest odmienna od wartości produktu przedstawianej w kategoriach stricte pieniężnych,

- nabywcę usługi, który w wielu przypadkach jest raczej konsumentem niż klientem, ponadto istnieje bardziej osobista relacja między sprzedawcą a nabywającym usługę,

- charakter usług decydujący o ich różnorodności, w przypadku towarów jest to stopień,

- niemagazynowalność,

- ekonomiczny charakter usług, będący kwestią dyskusyjną, gdyż występują podmioty nastawione na zysk oraz organizacje typu non profit,

- marketing stosowany w usługach, który jest narzędziem specjalistycznym,

- nieprecyzyjne standardy usług,

- pojawiające się różnice w kształtowaniu cen w tych samych kategoriach usług,

- trudności w stosowaniu zasad ekonomii w odniesieniu do usług, ponieważ mają one niematerialny charakter, 
- występowanie dużej ilości różnych, połączonych ze sobą korzyści,

- ograniczoną koncentrację w usługach,

- działalność marketingową wpływającą na wyróżnianie się na rynku usług,

- podejście do usługi raczej jako do czynności niż do stanu posiadania (Rathmell, 1966).

Duża liczba cech opisujących usługę pokazuje, że świadczenie usługi jest procesem zdecydowanie odmiennym od produkcji czy sprzedaży towarów.

W opinii autora każda z wymienionych cech wyróżniających usługi jest skorelowana z procesem świadczenia usługi. Różnorodność świadczonych usług w zglobalizowanej gospodarce światowej warunkuje powstawanie nowych elementów je wyróżniających. Jest to właściwy punkt wyjścia do prowadzenia badań identyfikujących nowe cechy charakterystyczne dla usług w XXI wieku.

0 tym, jak wykonana usługa będzie postrzegana przez klienta, decydują atrybuty jakości usług. Należą do nich: wymiar materialny, niezawodność usługi, reakcja na oczekiwania klienta, kompetencja, empatia, bezpieczeństwo, wiarygodność, terminowość i osiągalność (Bareja, Giedroyć, 2007).

Na wymiar materialny składają się: wyposażenie niezbędne do wyświadczenia danej usługi i wygląd pomieszczeń, a także zachowanie, nastawienie oraz prezencja personelu. Każda usługa powinna zostać wykonana przez usługodawcę solidnie i niezawodnie. Bardzo istotna jest właściwa reakcja na oczekiwania klienta - w razie pojawiających się problemów niezbędna jest natychmiastowa pomoc dla usługobiorcy.

Fachowość i wiedza personelu w danym zakresie oraz umiejętność pozyskiwania przez niego klientów będzie świadczyła o jego odpowiednich kompetencjach. Podczas świadczenia usług niezbędne jest zrozumienie oczekiwań klienta i traktowanie jego potrzeb w sposób zindywidualizowany (empatia). Brak tej cechy nie wpłynie dobrze na pozytywny odbiór usługodawcy przez usługobiorcę.

Niezapewnienie klientowi bezpieczeństwa i niepotrzebne narażanie go na ryzyko również będzie skutkowało negatywnym odbiorem. Konsument ceni też dobry i bezproblemowy kontakt z dostawcą usługi oraz łatwość jej pozyskania.

Wiarygodność usługodawcy będzie zależała od jego szczerości, a także od tego czy potrafi on terminowo realizować zlecone usługi. W takich warunkach buduje się dobra relacja między klientem a usługodawcą, która może wpłynąć na zawiązanie długotrwałych więzi. Zadowolony konsument na pewno skorzysta ponownie z usług tego przedsiębiorstwa i poleci je w swoich kręgach jako godne zaufania i sprawdzone.

Na jakość usługi ma wpływ wiele detali. Zaniedbanie któregoś z nich może przyczynić się do negatywnej oceny przez klienta wyświadczonej usługi, dlatego tak ważna jest dbałość o każdy z nich.

W badaniu jakości usług wykorzystywany jest model, który pozwala zidentyfikować i zrozumieć niezadowolenie klientów z powodu nieodpowiedniej jakości świadczonych usług oraz skutecznie mu przeciwdziałać. Wskazuje on miejsca, w których jakość oferowanej usługi może odbiegać od jakości, której oczekuje klient. Wyodrębnia się pięć luk jakości usług: pomiędzy oczekiwaniami klienta a percepcją usługodawcy, pomiędzy oceną kadry zarządzającej a specyfikacją jakości usługi, pomiędzy specyfikacją jakości usługi a faktycznym poziomem jej wykonania, pomiędzy jakością świadczonej usługi a reklamą i innymi formami komunikacji z klientem oraz pomiędzy usługą otrzymaną a oczekiwaną (Kachniewska, 2002). 
Badacze sektora usługowego są zgodni, iż wysoka jakość usług wpływa na pozytywne wyróżnienie się na tle konkurencji oraz pozwala osiągnąć przewagę konkurencyjną i podwyższyć wydajność. Dodatkowymi korzyściami wysokiej jakości usług są też m.in. wyższy stopień satysfakcji klientów oraz ich lojalność wbec organizacji, pozytywna opinia o organizacji obecnych i potencjalnych klientów, niski stopień rotacji pracowników, niskie koszty operacyjne i wyższa zyskowność oraz większy udział w rynku (Kostera, Śliwa, 2012).

Autorzy specjalizujący się w zarządzaniu jakością mówią jednym głosem o występowaniu silnej dodatniej korelacji pomiędzy jakością danej usługi postrzeganej przez klientów a ich satysfakcją (Bei, Chiao, 2006).

\section{FUNKCJE SEKTORA USŁUGOWEGO}

W literaturze przedmiotu powszechnie stosowane jest pojęcie „sfera usług”, które odnosi się do makroekonomicznego punktu widzenia i odpowiada definicji trzeciego sektora, który grupuje wszystkie działy gospodarki z wyłączeniem rolnictwa, leśnictwa, przemysłu i budownictwa (Niewadzi, 1975).

Podział gospodarki na trzy sektory - pierwszy (rolnictwo, leśnictwo, rybołówstwo), drugi (przemysł i budownictwo) i trzeci (sfera usług) - wykorzystywany jest szeroko do badań naukowych struktury gospodarczej w ujęciu makroekonomicznym. Sfera usług nie rozgranicza jednoznacznie jednostek świadczących usługi od jednostek wytwórczych (Niewadzi, 1975).

Poziom rozwoju sektora usługowego wpływa na rozwój gospodarki narodowej i życia społeczeństw. Przedsiębiorstwa świadczące usługi oddziałują na produkcję, wymianę, konsumpcję, a także na życie ludzi. Funkcje pełnione przez sektor usługowy można podzielić na dwie grupy: gospodarcze oraz pozagospodarcze.

Ryc. 1. Funkcje gospodarcze sektora usługowego

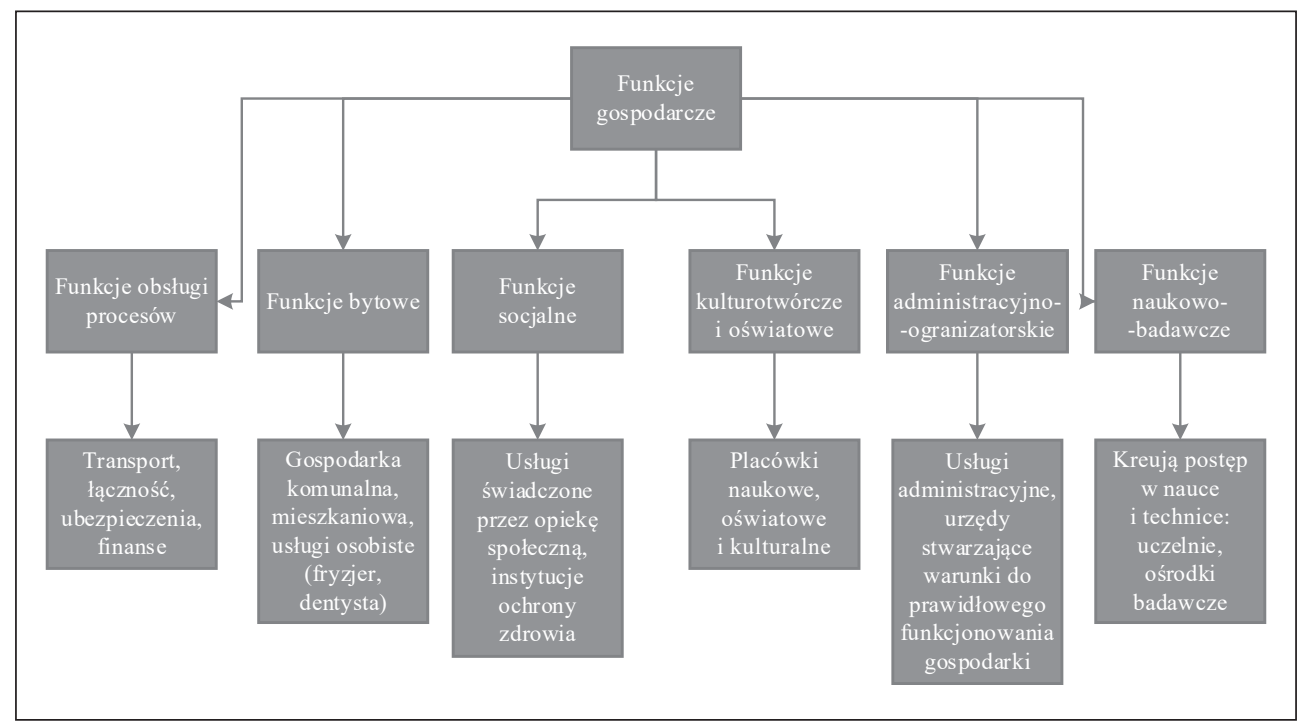

Źródło: opracowanie własne na podstawie: Rogoziński (2000) 
Do najważniejszych funkcji gospodarczych (ryc. 1) zalicza się te związane z obsługą procesów wytwórczych, bytowe, socjalne, kulturotwórcze i oświatowe, administracyjno-organizatorskie i naukowo-badawcze (Rogoziński, 2000).

Funkcje obsługi procesów polegają na wytwarzaniu dóbr materialnych i realizowane są przez takie sektory, jak: handel, transport, finanse, ubezpieczenia, łączność. Działania, które mają na celu zaspokojenie potrzeb bytowych ludności poprzez takie dziedziny działalności usługowej, jak: gospodarka komunalna, gospodarka mieszkaniowa, łączność, usługi osobiste (fryzjer, kosmetyczka), handel, transport - to funkcje bytowe. Natomiast funkcje socjalne świadczone są przez opiekę społeczną, instytucje kultury fizycznej oraz ochrony zdrowia.

Funkcje kulturotwórcze i oświatowe dotyczą rozwoju placówek naukowych, oświatowych i kulturalnych, a ich realizacja następuje poprzez upowszechnianie i podnoszenie poziomu nauki i kultury w społeczeństwie. Do funkcji administracyjno-organizatorskich należą czynności, które stwarzają warunki do prawidłowego funkcjonowania gospodarki narodowej opartej na jednostkach administracji gospodarczej. Działania związane z kreowaniem postępu w nauce, technice i organizacji oraz mające odzwierciedlenie w rozwoju badań naukowych i ich zastosowaniu w praktyce - to funkcje naukowo-badawcze (Rogoziński, 2000).

Najistotniejszymi funkcjami pozagospodarczymi są funkcje obronne, administracyjne, porządku publicznego, inne funkcje aparatu władzy oraz pozostałe funkcje związane ze sferą pozagospodarczą organizacji.

W opinii C. Niewadziego linia podziału funkcji usług na gospodarcze, społeczno-gospodarcze i pozagospodarcze biegnie $\mathrm{w}$ wielu przypadkach nie pomiędzy działami gospodarki narodowej, ale wewnątrz nich, jak też w obrębie poszczególnych gałęzi gospodarki (Niewadzi, 1975).

Grupy funkcji gospodarczych i pozagospodarczych pokazują, że usługi są obecne we wszystkich sektorach gospodarki i ciężko sobie wyobrazić funkcjonowanie państw, społeczeństw, miast bez ich udziału. Autor wyróżnia dodatkową grupę funkcji finansowych, związanych ze wszystkimi świadczonymi usługami w zakresie finansów na rzecz klientów indywidualnych i biznesowych. Dzisiejsze gospodarki osadzone są w realiach zglobalizowanego świata, w którym najważniejszy jest szybki przepływ wiedzy, kapitału, technologii i idei. Swobodny transfer środków finansowych to konieczność XXIwieku,zaktórąodpowiadająinstytucjefinansowe. Realizacjazaprezentowanychfunkcji wiąże się z licznymi problemami, których doświadczają przedsiębiorstwa usługowe.

\section{PROBLEMY ZARZĄDZANIA W PRZEDSIĘBIORSTWACH USŁUGOWYCH}

Obszary problemowe występujące w podmiotach świadczących usługi wynikają z ich charakterystycznych cech. Szczególnie istotną kwestią jest wzajemna interakcja zachodząca między usługobiorcą a usługodawcą, która wpływa na subiektywną ocenę wyświadczonej usługi przez konsumenta. Na właściwe zarządzanie przedsiębiorstwem usługowym oddziałuje również nietrwałość, która determinuje opracowanie odpowiedniego planu świadczenia usług uwzględniającego aktualny popyt i podaż. Niska jakość świadczonej usługi może spowodować odpływ klientów, natomiast wysoka będzie odpowiednią reklamą dla potencjalnych nowych usługobiorców. Wszystkie pojawiające się problemy w organizacjach usługowych (ryc. 2) wpływają na to, jak postrzegane są te podmioty przez obecnych i potencjalnych klientów oraz konkurencję rynkową. 
Ryc. 2. Problemy zarządzania przedsiębiorstwem usługowym

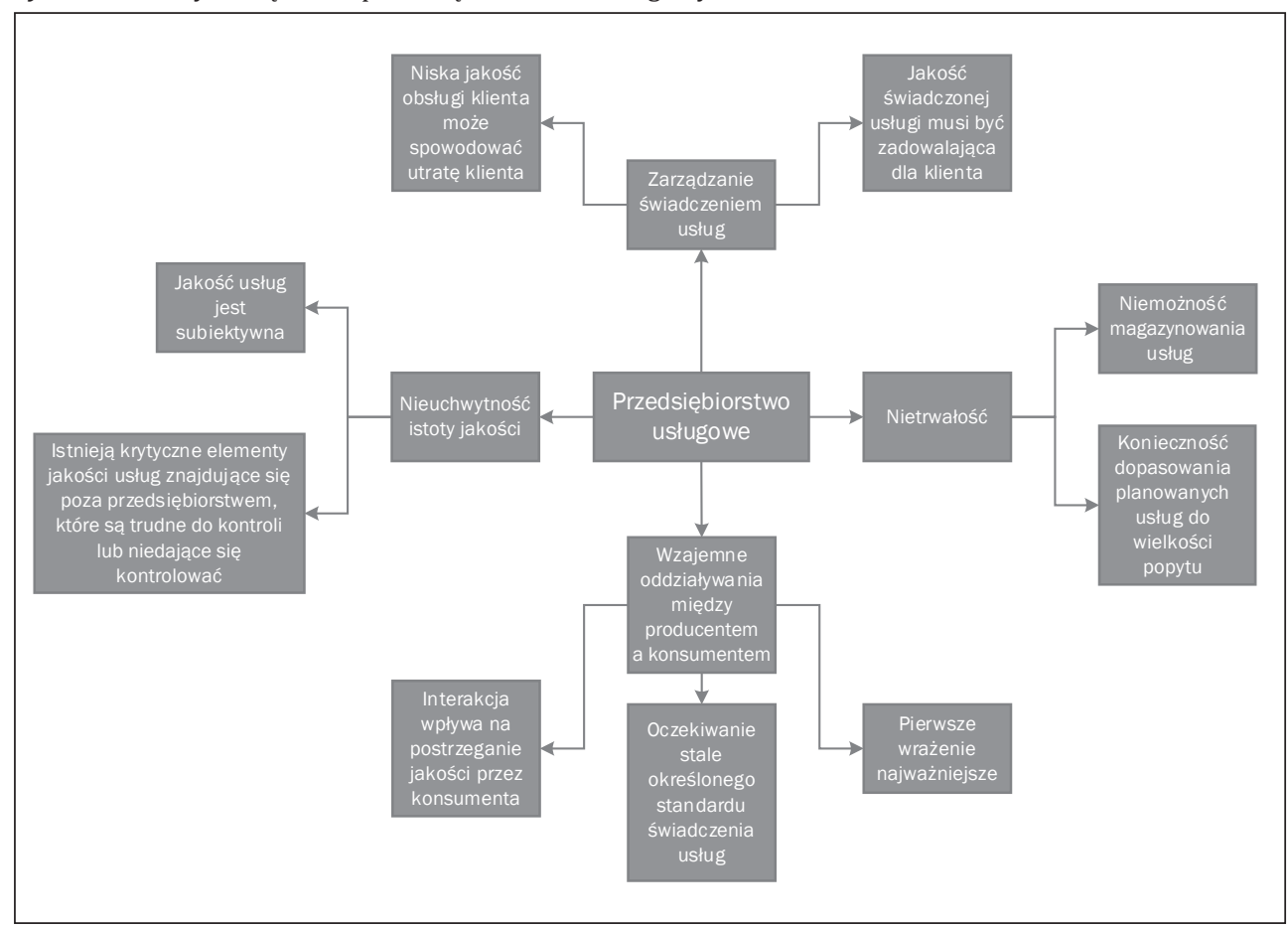

Źródło: opracowanie własne na podstawie Drummond (1998)

Problemy zarządzania wynikające z zarządzania świadczeniem usług wiążą się nie tylko z niedopasowania jakości usług, ale także ze sposobu ich świadczenia. Niezadowalająca jakość obsługi może np. spowodować opuszczenie restauracji przez klientów, nawet pomimo serwowania bardzo dobrych dań.

Kolejną kwestię stanowi nietrwałość usług, które w przeciwieństwie do dóbr materialnych nie mogą być magazynowane. Konieczne staje się ich dopasowanie do wielkości popytu, co przysparza zarządzającym dużo trudności. Dentysta nie może zmagazynować swej usługi i świadczyć jej równocześnie wielu klientom w czasie największego ruchu. Istotne jest więc zapewnienie odpowiedniej dostępności usług w okresach jej świadczenia (Gilmore, 2006).

W przedsiębiorstwach usługowych występuje silna interakcja między producentem a konsumentem, która ma wpływ na percepcję jakości. Postrzeganie jakości w podmiotach usługowych uzależnione jest od tzw. chwili wiarygodności, która następuje w czasie kontaktu producenta z konsumentem. Zaprezentowana wiarygodność usługodawcy jest istotna, ponieważ umiejętnie przedstawiona może spowodować satysfakcję lub - w wypadku nieodpowiedniej obsługi - efekt przeciwny. Przykładem jest menu $\mathrm{w}$ restauracji przygotowane $\mathrm{w}$ ten sposób, aby pobudzało dyskusję między klientem a kelnerem dla wywołania dobrego wrażenia. Zbytni pośpiech kelnera w rozmowie lub brak odpowiedzi na postawione przez konsumenta pytania spowoduje jego rozczarowanie (Drummond, 1998).

Wobec firm usługowych oczekuje się świadczenia usług w stale określonym standardzie. Liczne usługi muszą być wykonywane „na żądanie”, nawet gdy warunki do ich 
realizacji są bardzo dalekie od doskonałości. W takiej sytuacji świadczenie usługi jest stosunkowo pracochłonne i wystawione na konflikty pomiędzy stronami ją realizującymi. Przedsiębiorstwa usługowe muszą zwracać szczególną uwagę na nastroje klientów i ich zachowania oraz relacje między nimi. Zachowania jednych klientów mogą spowodować negatywne reakcje u drugich, co doskonale obrazuje przykład widzów w kinie, których może zirytować fakt, że inni widzowie prowadzą rozmowy w czasie seansu filmowego (Stoma, 2012).

Zakres przyczyn mogących wywołać złe odczucia u konsumentów jest duży, jednak niepowodzenie może być obrócone w sukces. Postępowanie zgodnie z niezadowoleniem klienta może przyczynić się do zmienienia go w entuzjastę. Występujące uchybienia należy wyrównać z naddatkiem, wtedy reakcja powinna być adekwatna do reklamacji.

Stały klient jest gotów do wybaczenia jednego, dwóch złych doświadczeń, niestety nowy, potencjalny klient nie wybacza żadnych uchybień. Utrata wiarygodności przez konsumenta niezwiązanego wcześniej z danym podmiotem usługowym może być utratą tego usługobiorcy na zawsze.

Jakość jest zawsze kwestią bardzo subiektywną. Jedna osoba może ocenić daną usługę jako zrealizowaną doskonale, natomiast drugi klient będzie uważał, że jest to usługa o niskiej jakości.

Oczekiwania usługobiorców są zindywidualizowane, ale dotyczą głównie technicznych i funkcjonalnych warunków usług. Techniczne ujęcie dotyczy sfery materialnej, wymiar funkcjonalny wiąże się ze świadczeniem usług, czyli sferą niematerialną (Camarero, 2007).

W literaturze pojawiły się różne koncepcje dotyczące zapewnienia wysokiej jakości usług przez pracowników. Do najważniejszych należą: łańcuch zysku usług, badania środowiska, pejzaże usług oraz badania klimatu w usługach.

Łańcuch zysku usług (service profit chain) opracowany został przez J.L. Hesketta i współautorów, którzy rozpatrywali organizację usługową jako jednostkę złożoną z ludzi i procesów wewnątrz organizacji. To ludzie i procesy wpływają na klientów oraz na przyszłe przychody i zyski w firmie. Podstawą tej koncepcji jest pojęcie „wewnętrznej jakości", służącej do wykonywania pracy, którą personel otrzymuje od przedsiębiorstwa. Wysoka jakość wewnętrzna daje pracownikom dobre warunki do wykonywania ich zadań, przez co świadczą oni klientom usługi wysokiej jakości. Niska jakość wewnętrzna, czyli np. praca personelu w warunkach stresowych i jego przekonanie o tym, że pracodawca nie pozwala na wykonywanie zadań na najwyższym poziomie, wpłynie na jakość usług oferowanych klientom (Davis, 2006).

Środowisko fizyczne w organizacji wpływa nie tylko na odczucia i doświadczenia klientów, ale również na pracowników - ich satysfakcję, produktywność i motywację. J. Bitner, która jest autorką koncepcji pejzaży usług, sugeruje, że projektowanie i kierowanie środowiskami w organizacjach usługowych powinno być konsultowane zarówno z klientami, jak i pracownikami w celu uniknięcia sytuacji przeszkadzania sobie wzajemnie w działaniu.

Ponadto motywacja i morale pracowników oddziałują na produktywność i jakość usług w przedsiębiorstwie usługowym. Efektywny system świadczenia usług jest oparty na współdziałaniu ludzi z dostępnym wyposażeniem, tworzeniu kreatywnych rozwiązań i skupieniu się na wykorzystaniu ludzkiego potencjału i energii (Normann, 2002). 
Ryc. 3. Perspektywa relacyjna w jakości świadczenia usług

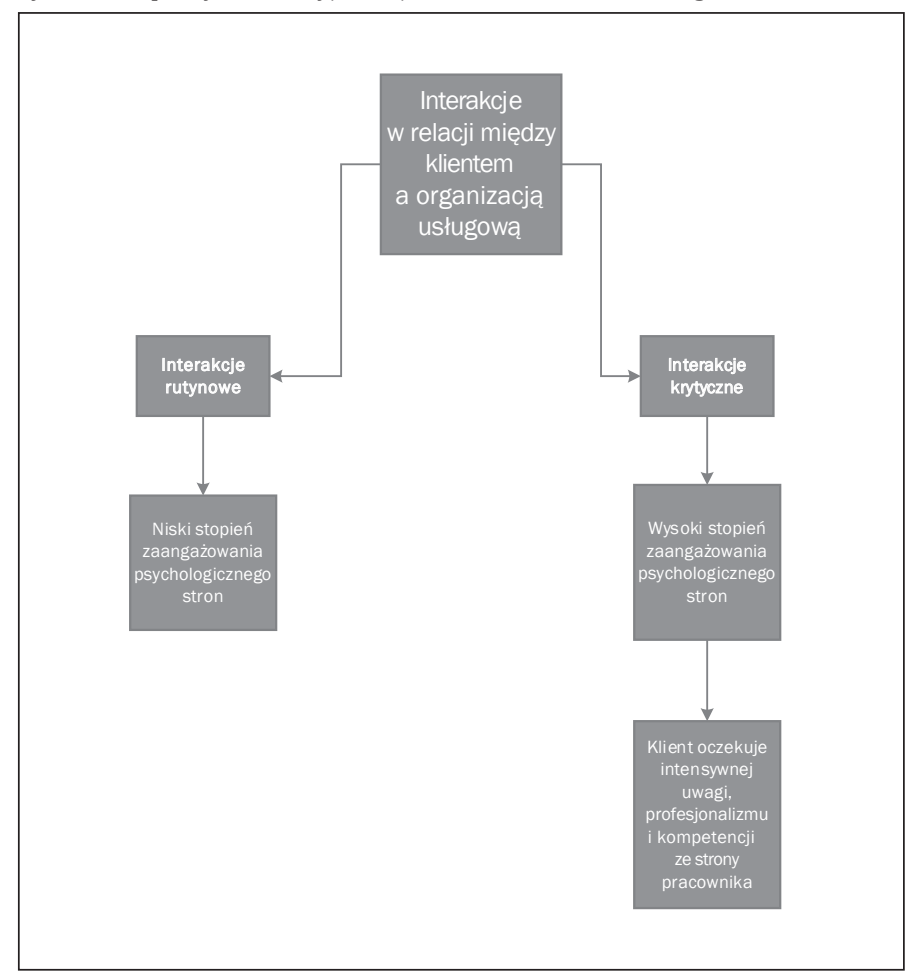

Źródło: opracowanie własne na podstawie Kostera, Śliwa (2012)

Zupełnie inne podejście do udziału pracowników w realizacji celów jakościowych usług prezentuje perspektywa relacyjna. Świadczenie usługi jest jednym z wielu elementów w całej sekwencji zdarzeń między klientem a organizacją. Pojawiają się dwa rodzaje interakcji: rutynowe i krytyczne (ryc. 3).

W podejściu relacyjnym klienci, oceniając jakość, kierują się nie tylko interakcją z podmiotem, ale biorą także pod uwagę szereg innych epizodów, z których złożona jest relacja (czasami długotrwała) między klientem a usługodawcą. Udział pracowników w budowaniu relacji między usługobiorcą a organizacją jest niezwykle istotny, ponieważ od tych stosunków zależy, jak klienci będą postrzegać i oceniać jakość usług w interakcjach krytycznych oraz jak wpłynie to na ocenę całej jakości, której dostarcza im dana organizacja w usługach (Bock, Garretson Folse, Black, 2016).

Mimo iż dominujące w procesie wytwarzania usług jest zadowolenie i satysfakcja użytkownika, to wiele koncepcji przemawia za poświęceniem większej uwagi pracownikowi, jego doświadczeniu i zaangażowaniu w świadczenie usług.

Pożądane są nowe koncepcje zarządzania, które sprostałyby współczesnym warunkom, co jest szczególnie uzasadnione w przypadku przedsiębiorstw usługowych, które są zdecydowanie bardziej czułe niż podmioty produkcyjne na zjawiska zachodzące we współczesnej gospodarce. Przykładem jest globalizacja, która ma silny wpływ na funkcjonowanie organizacji świadczących usługi, np. transportowe, bankowe czy turystyczne. Podmioty te muszą stawić czoło nie tylko globalnej konkurencji, ale również 
umiejętnie korzystać z globalnych zasobów. Bez sprawnego wykorzystania technologii informatycznej oraz bez integracji systemu z działalnością firmy będzie to niemożliwe.

Konieczne jest zatem spojrzenie na sektor usług z kilku perspektyw (Panasiuk, Tokarz, 2008). Pierwsza zakłada istnienie globalnego klienta, którego zachowanie i sposób myślenia wykracza poza obszar lokalny czy regionalny, np. popyt na usługi turystyczne, finansowe, medyczne. W drugiej konieczne jest dążenie do wykorzystania efektu skali w celu optymalizacji kosztów usług. Kolejne spojrzenie dotyczy rozwoju technologii informatycznych, będących katalizatorem sposobu świadczenia usług w XXI wieku. Natomiast ostatnia perspektywa zakłada powstawanie tendencji do liberalizacji rynków i tworzenia ram prawnych, pozwalających na wejście na rynek i konkurowanie wszystkim przedsiębiorstwom (Downar, 2008).

Zjawiska te poszerzają przestrzeń świadczenia usług i są wyzwaniem zarówno dla tworzących strategie i politykę gospodarczą w sektorze usług, jak i dla kierujących przedsiębiorstwami usługowymi. Wspólnym mianownikiem nowych koncepcji (zarządzanie przez jakość, zarządzanie marketingowe) i metod zarządzania (metody planowania produkcji) jest klient i jego potrzeby. Praktycznym środkiem do zaspokojenia potrzeb konsumenta jest wykorzystanie w podmiotach usługowych procesu i zarządzania procesowego.

\section{ZAKOŃCZENIE}

W literaturze przedmiotu, a także w prawie krajowym i prawie Unii Europejskiej występują liczne definicje pojęcia usługi, rozumianej przez większość autorów jako odpłatne świadczenie, które nie jest sprzedażą towarów, ale dotyczy zaspokojenia potrzeb usługobiorcy.

Przedsiębiorstwa usługowe są specyficznymi podmiotami, które od jednostek produkcyjnych różnią się takimi cechami, jak m.in.: niematerialność, heterogeniczność oraz niemożność przechowania dla celów przyszłej konsumpcji.

Funkcje pełnione przez sektor usługowy dzielą się na gospodarcze i pozagospodarcze. Potwierdzają one obecność usług we wszystkich sektorach gospodarki i ciężko sobie wyobrazić funkcjonowanie społeczeństw, miast i państw bez ich udziału.

Podczas realizacji swoich funkcji przedsiębiorstwa usługowe muszą borykać się z licznymi problemami, które mają swoje źródło w nietrwałości usług, niskiej jakości obsługi klienta, subiektywizmie jakości usługi oraz wzajemnej interakcji pomiędzy usługodawcą a usługobiorcą i jej specyfice.

Mimo iż dominujące w procesie wytwarzania usług jest zadowolenie i satysfakcja użytkownika, to wiele koncepcji przemawia za poświęceniem większej uwagi pracownikowi, jego doświadczeniu i zaangażowaniu w świadczenie usług.

Konieczne są nowe koncepcje i metody zarządzania, które odpowiadałyby współczesnym warunkom świadczenia usług. Ich częścią wspólną jest klient i jego potrzeby. Zaspokojenie potrzeb konsumenta będzie możliwe w przedsiębiorstwach usługowych, które są zorientowane na zarządzanie procesowe i prowadzą rachunek kosztów jakości.

Zebrana i przedstawiona w artykule wiedza teoretyczna na temat usług i działalności usługowej może być dobrą bazą do dalszych badań nad wpływem jakości usług na rachunek kosztów jakości wykorzystywany przez przedsiębiorstwa usługowe do optymalizacji kosztów. 


\section{Literatura \\ References}

Bareja, K., Giedroyć, M. (2007). Rachunek kosztów jakości. W: A. Karmańska (red.). Zarządzanie kosztami jakości, logistyki, innowacji, ochrony środowiska a rachunkowość finansowa. Warszawa: Difin, 31-69.

Bei, L.T., Chiao, Y.C., (2006). The determinants of customer loyalty: An analysis of intangible factors in three service industries. International Journal of Commerce and Management, 16(3-4), 162-177.

Bock, D.E., Garretson Folse, J.A., Black, W.C. (2016). Gratitude in service encounters: implications for building loyalty. Journal of Services Marketing, 30(3), 341-358.

Camarero, C. (2007). Relationship orientation or service quality? International Journal of Bank Marketing, 25(6), 406-426.

Chrząścik, M. (2009). Zarządzanie jakością usług publicznych. W: J. Toruński (red.). Zarządzanie jakościq $w$ przedsiębiorstwie. Wybrane problemy. Siedlce: Wydawnictwo Akademii Podlaskiej, 172-205.

Davis, P.J. (2006). In search of the common wealth: a service-profit chain for the public sector. International Journal of Productivity and Performance Management, 55(2), 163-172.

Downar, W. (2008). Zarządzanie procesowe w przedsiębiorstwie usługowym. W: B. Filipiak, A. Panasiuk (red.). Przedsiębiorstwo usługowe. Zarzq̨dzanie. Warszawa: Wydawnictwo Naukowe PWN, 36-57.

Drummond, H. (1998). W pogoni za jakością. Total Quality Management. Warszawa: Dom Wydawniczy ABC.

Gilmore, A. (2006). Usługi. Marketing i zarządzanie. Warszawa: Polskie Wydawnictwo Ekonomiczne.

Gustafsson, A., Johnson, M.D. (2003). Competing in a Service Economy, How to Create a Competitive Advantage Through Service Development and Innovation. San Francisco: John Wiley \& Sons, Inc.

Illeris, S. (1996). The Service Economy: A Geographical Approach. Chichester: Wiley.

Kachniewska, M. (2002). Zarzq̨dzanie jakościq usług turystycznych. Warszawa: Difin.

Kolman, R. (2013). Różne odmiany jakości i ich praktyczne wykorzystanie. Warszawa: Wydawnictwo Placet.

Kostera, M., Śliwa, M. (2012). Zarządzanie w XXI wieku. Jakość, twórczość, kultura. Warszawa: Wolters Kluwer.

Lange, O. (1967). Ekonomia polityczna. Tom 1: Zagadnienia ogólne. Warszawa: Państwowe Wydawnictwo Naukowe.

Michalski, E. (2012). Marketing. Podręcznik akademicki. Warszawa: Wydawnictwo Naukowe PWN.

Niewadzi, C. (1975). Usługi w gospodarce narodowej. Warszawa: Państwowe Wydawnictwo Ekonomiczne.

Normann, R. (2002). Service Management. Strategy and leadership in service business. John Wiley \& Sons.

Panasiuk, A. (2005). Koncepcja marketingu usług. W: A. Panasiuk (red.). Marketing usług turystycznych. Warszawa: Wydawnictwo Naukowe PWN, 13-23.

Panasiuk, A., Tokarz, A. (2008). Wstęp do ekonomiki przedsiębiorstwa usługowego. W: B. Filipiak, A. Panasiuk (red.). Przedsiębiorstwo usługowe. Ekonomika. Warszawa: Wydawnictwo Naukowe PWN, 29-46.

Polska 2015. Raport o stanie gospodarki (2015). Warszawa: Ministerstwo Gospodarki.

Rathmell, J.M. (1966). What Is Meant by Services? Journal of Marketing, 30, 32-36.

Rogoziński, K. (2000). Usługi rynkowe. Poznań: Akademia Ekonomiczna w Poznaniu.

Sadkowski, W. (2017). Identyfikacja skali wdrażania certyfikowanych systemów zarządzania jakością w przedsiębiorstwach usługowych. Prace Komisji Geografii Przemysłu Polskiego Towarzystwa Geograficznego, 31(1), 97-107.

Stoma, M. (2012). Modele i metody pomiaru jakości usług. Lublin: Q\&R Polska Sp. z o.o. 
Traktat o funkcjonowaniu Unii Europejskiej (2012, 26 października). Pozyskano z http://eur-lex. europa.eu/legal-content/PL/TXT/PDF/?uri=CELEX:12012E/TXT\&from=PL

Ustawa z dnia 4 marca 2010 r. o świadczeniu usług na terytorium Rzeczypospolitej Polskiej (Dz.U. nr 47, poz. 278, art. 2).

Wojciech Sadkowski, mgr, Uniwersytet Jagielloński, Wydział Zarządzania i Komunikacji Społecznej, Instytut Ekonomii, Finansów i Zarządzania, Katedra Rachunkowości Międzynarodowej. Zainteresowania badawcze: rachunek kosztów jakości, rachunkowość zarządcza, bankowość korporacyjna, sektor małych i średnich przedsiębiorstw, upadłość przedsiębiorstw.

Wojciech Sadkowski, M.Sc., Jagiellonian University, Faculty of Management and Social Communication, Institute of Economics, Finance and Management, Department of International Accounting. Research interests: quality costs calculation, managerial accounting, corporate banking, small and medium enterprises, company bankruptcy.

\section{Adres/address:}

Uniwersytet Jagielloński

Wydział Zarządzania i Komunikacji Społecznej

Instytut Ekonomii, Finansów i Zarządzania

Katedra Rachunkowości Międzynarodowej

ul. prof. S. Łojasiewicza 4, 30-348 Kraków, Polska

e-mail:wojciech.sadkowski@uj.edu.pl 